Article history

Received Oct 30, 2020

Accepted Apr 28, 2021

\title{
UJI VALIDITAS DAN RELIBILITAS INSTRUMEN PENGUKURAN IMPLEMENTASI E-LEARNING TERHADAP KEPUASAN PENGGUNA PADA MASA PANDEMI COVID19 DI LINGKUNGAN POLITEKNIK NEGERI BANJARMASIN
}

\author{
Rahimi Fitri ${ }^{1)}$, Syamsudin Noor' ${ }^{1)}$, Ida Hastuti ${ }^{1)}$ \\ ${ }^{1}$ Jurusan Teknik Elektro, Prodi D3 Teknik Informatika, Politeknik Negeri Banjarmasin \\ email: rahimi_fitri@poliban.ac.id,SSyamsudin@ @oliban.ac.id,dhaplbn@gmail.com
}

\begin{abstract}
The implementation of online lectures requires adequate preparation and support of resources, including the first is the software or tools used in online lectures, where Poliban has e-learning that can be used or can use other tools. Both hardware or computer equipment with the required specifications, one of which is a camera used for video conferencing, and what is very important is a stable internet network connection. Therefore, if at least these three things can be fulfilled, then online lectures can be carried out well. However, in reality there are several problems faced by both lecturers and students, especially related to the unstable internet network signal, so that the implementation of online lectures cannot run optimally. To find out the problems faced by users, an instrument to measure the implementation of E-learning on user satisfaction is needed. In making a good instrument model, a test is needed to ensure that the indicators used in the instrument used are valid and reliable and have a good level of reliability. Based on the background previously mentioned, this study tested the e-learning implementation measurement tool for user satisfaction at the Politeknik Negeri Banjarmasin with the validity and reliability test models using the Partial Least Square (PLS) framework. The PLS model is a statistical model that can be used to estimate the calculation of the relationship strength of the hypothesis among the variables in the theoretical model. The results of the validity test of this study get a loading factor value above 0.5 against the intended construct, this indicates that the indicators used in this study are valid or have met convergent validity. Furthermore, the results of the reliability test resulted in a composite reliability value above 0.7 for all constructs which indicated that all constructs in the planned model had met the discriminant validity criteria. Based on the test, the lowest composite reliability value is 0.837 in the System Quality construct, this value indicates that the test equipment shows a good level of reliability, or it can be said that the results of the questionnaire that have been made are reliable.
\end{abstract}

Keywords: Validity Test, Reliability Test, Instruments, E-learning Measurement, User Satisfaction

\begin{abstract}
Abstrak
Pelaksanaan kuliah secara daring memerlukan persiapan dan dukungan sumber daya yang memadai antara lain pertama adalah Software atau tools yang digunakan dalam perkuliahan daring, dimana Poliban memiliki elearning yang bisa dimanfaatkan atau bisa menggunakan tools lainnya. Kedua Hardware atau perangkat computer dengan spesifikasi yang diperlukan salah satunya ada kamera yang digunakan untuk video conference, dan yang sangat penting adalah koneksi jaringan internet yang stabil. Oleh karenanya jika minimal tiga hal tersebut dapat terpenuhi, maka perkuliahan secara daring dapat terlaksana dengan baik. Akan tetapi dalam realitanya ada beberapa masalah yang dihadapi baik oleh dosen maupun mahasiswa terutama terkait sinyal jaringan internet yang kurang stabil, sehingga pelaksanaan kuliah daring tidak dapat berjalan maksimal. Untuk mengetahui permasalahan yang dihadapi pengguna dibutuhkan suatu instrument pengukuran implementasi E-learning terhadap
\end{abstract}


kepuasan pengguna. Dalam pembuatan suatu model instrument yang baik diperlukan suatu pengujian untuk memastikan bahwa indicator yang digunakan dalam instrument yang digunakan valid dan dapat dipercaya dan memiliki tingkat reliabilitas yang baik Berdasarkan latar belakang yang telah disebutkan sebelumnya maka penelitian ini melakukan pengujian instrumen implementasi e-learning terhadap kepuasan pengguna di Politeknik Negeri Banjarmasin dengan model uji validitas dan uji reliabilitas menggunakan framework Partial Least Square (PLS). Model PLS merupakan suatu model statistik yang dapat digunakan untuk memperkirakan perhitungan kekuatan relasi dari hipotesis di antara variabel dalam model teoritis Hasil uji validitas dari penelitian ini mendapatkan nilai loading factor di atas 0,5 terhadap konstruk yang dituju, hal ini menunjukkan bahwa indikator yang digunakan dalam penelitian ini bernilai valid atau telah memenuhi convergent validity. Selanjutnya hasil uji reliabilitas menghasilkan nilai composite reliability diatas 0,7 untuk semua konstruk yang menunjukkan bahwa semua konstruk pada model yang direncanakan telah memenuhi kriteria discriminant validity. Berdasarkan pengujian tersebut nilai composite reliability yang paling rendah adalah sebesar 0,837 pada konstruk Kualitas Sistem, nilai ini menunjukkan bahwa alat uji menunjukkan tingkat reliabilitas yang baik, atau dapat dikatakan bahwa hasil angket yang telah dibuat dapat dipercaya.

Kata Kunci: Uji Validitas, Uji Reliabilitas, Instrumen, Pengukuran E-learning, Kepuasan Pengguna.. 


\section{PENDAHUlUAN}

Perpres Nomor 72 Tahun 2019 tentang Kementerian Pendidikan dan Kebudayaan (Kemendikbud) tentang urusan pendidikan tinggi kembali di bawah Kemendikbud dengan Tugas yaitu "menyelenggarakan urusan pemerintahan dibidang pendidikan anak usia dini, pendidikan dasar, pendidikan menengah, pendidikan tinggi, dan pendidikan masyarakat, serta pengelolaan kebudayaan untuk membantu Presiden dalam menyelenggarakan pemerintahan negara" (Pasal 4)[1].

Berdasarkan Undang-Undang Repulbik Indonesia nomor 22 tahun 1961 tentang perguruan tinggi disebutkan pada pasal 1 bahwa "Perguruan tinggi merupakan lembaga ilmiah dengan tugas mengadakan pendidikan dan pengajaran diatas perguruan tingkat menengah, dan yang memberikan pendidikan dan pengajaran berdasarkan kebudayaan kebangsaan Indonesia dan dengan cara ilmiah". Penyelenggaraan Pendidikan di perguruan tinggi diatur oleh pemerintah Republik Indonesia melalui Direktorat Jenderal Kelembagaan Ilmu Pengetahuan, Teknologi, dan Pendidikan Tinggi dalam Kementerian Pendidikan dan Kebudayaan (Kemendikbud).

Pada tahun 2020 tepatnya pada tanggal 9 Maret 2020, kemendikbud menerbitkan surat edaran Nomor 3 Tahun 2020 Tentang "Pencegahan Penyebaran virus Covid-19 pada Satuan Pendidikan", dimana pandemic covid-19 ini sangat perlu mendapatkan perhatian dari semua kalangan termasuk dunia Pendidikan tinggi[2]. Selanjutnya guna mempertegas terkait pelaksanaan pembelajaran di perguruan tinggi mendikbud menerbitkan surat pada 17 Maret 2020 dengan Nomor: 36962/MPK.A/HK/2020 tentang "Pembelajaran secara Daring dan Bekerja dari Rumah dalam rangka Pencegahan Penyebaran Corona Virus Disease (COVID-19)".

Berdasarkan kondisi tersebut, maka Direktur Poliban menerbitkan surat edaran Nomor : 614/PL18/KL/2020 tentang "Pencegahan Penyebaran virus Covid-19 di Lingkungan Politeknik Negeri Banjarmasin" dan kegiatan pembelajaran di lingkungan Poliban dilaksanakan secara daring menggunakan E-Learning.

Sebagai salah satu solusi penerapan pembelajaran secara daring di masa pandemic COVID19, Politeknik Negeri Banjarmasin telah memiliki E-Learning yang telah digunakan oleh sebagian besar pengajar.

Secara umum E-Learning memiliki keunggulan yaitu mampu memberikan pemecahan masalah dengan memberikan pembelajaran yang lebih mudah, menerapakan teknologi tanpa kertas, memelihara standar dan dan menjamin kualitas pendidikan yang tinggi dan proses pembelajaran dapat dilakukan dimana saja dengan persyaratan yaitu terdapat jaringan internet[3].

Selain keunggulan tersebut, implementasi ELearning juga memiliki kekurangan jika ditinjau dari pengguna (Dosen dan Mahasiswa) yaitu pengguna mengalami kesulitan dalam pencapaian keberhasilan strategis, tidak tercapainya tujuan umum dan tujuan khusus dari penyampaian materi, efektivitas dan dan kesulitan bagi mahasiswa dalam penerimaan materi pembelajaran. Kesulitan dalam beradaptasi dengan pembelajaran online dan penggunaan teknologi, tentu saja akan menimbulkan frustasi tersendiri bagi dosen dan mahasiswa karena selain harus terbebani dengan matakuliah itu sendiri, juga dalam hal beradaptasi dengan teknologi E-Learning.

Permasalahan ini mendorong penulis untuk mengembangkan suatu model instrumen pengukuran implementasi E-learning terhadap kepuasan pengguna pada masa pandemi COVID19 di lingkungan Politeknik Negeri Banjarmasin. Instrumen yang digunakan disusun dengan menerapkan teori-teori dalam pengembangan model Technology Acceptance Model (TAM). TAM merupakan model yang paling sering digunakan untuk penelitian yang berhubungan dengan pengukuran kesuksesan penerapan sistem informasi. Model ini disusun berdasarkan proses relasi kausal antar dimensi, sehingga proses pengukuran kesuksesan sistem informasi dilakukan secara keseluruhan, dimana satu variable mempengaruhi variable yang lainnya[4]

Agar instrumen yang dibuat dapat digunakan untuk melakukan pengukuran maka instrument tersebut harus diuji validitas dan reliabilitas sehingga instrument yang digunakan valid dan dapat dipercaya.

Berdasarkan pembahasan yang telah disebutkan sebelumnya, maka penelitian ini dilakukan dengan menggunakan uji validitas dan uji reliabilitas terhadap instrumen pengukuran implementasi E-learning terhadap kepuasan pengguna di Politeknik Negeri Banjarmasin.

Penelitian ini bertujuan agar perangkat yang akan digunakan untuk melakukan pengukuran implementasi E-learning pada kepuasan pengguna di Politeknik Negeri Banjarmasin teruji 
validitas dan reliabilitas nya, sehingga dapat digunakan untuk proses selanjutnya.

\section{METODE PENELITIAN}

Skema besar dari penelitian ini adalah mengukur implementasi E-learning pada kepuasan pengguna di Politeknik Negeri Banjarmasin. Pada jurnal ini penulis mempersempit area pembahasan yaitu pada area pengujian instrument yang akan digunakan untuk skema besar penelitian. Gambar 1 berikut ini adalah focus area penelitian yang dilakukan guna menyelesaikan permasalahan yang telah disebutkan sebelumnya.

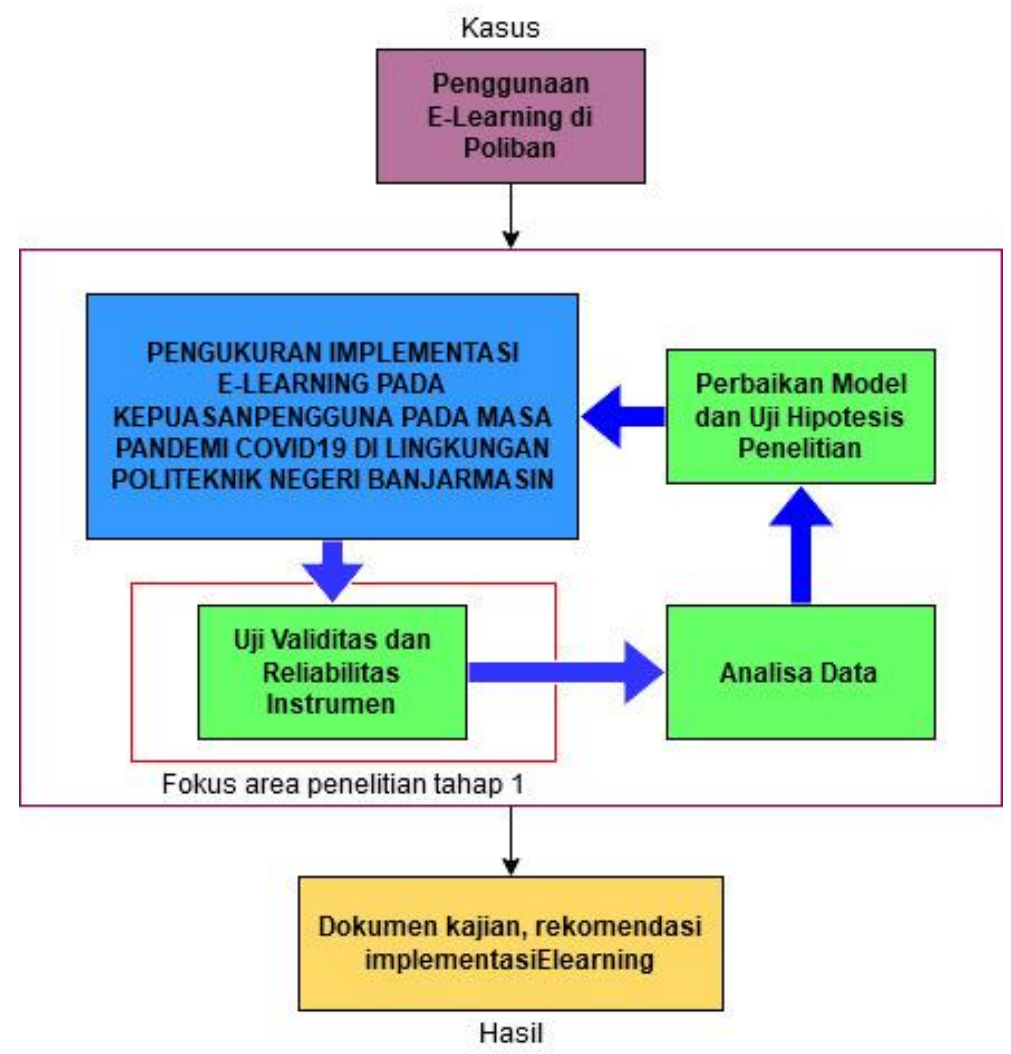

Gambar 1. Fokus Area Penelitian

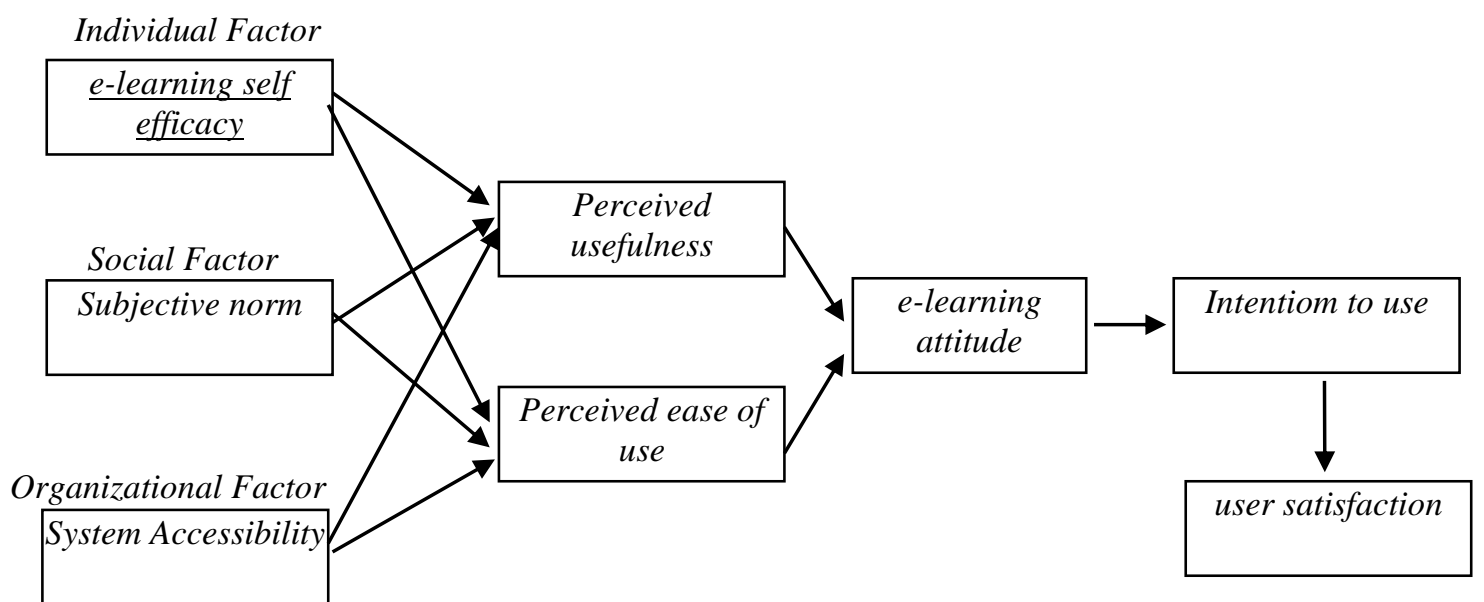

Gambar 2. Model Instrumen penelitian 
Untuk memperjelas kerangka pikir penyelesaian penelitian, maka dibuatlah model instrumen yang merupakan modifikasi dari model DeLone dan McLean, seperti yang terlihat pada gambar 2.

Variable penelitian ini disusun berdasarkan TAM yang merupakan salah satu model yang dibangun untuk menganalisa dan memahami factor apa saja yang mempengaruhi diterimanya penggunaan teknologi computer. Teknologi ini diperkenalkan pertama kali oleh Fred Davis pada tahun 1986. Berikut ini adalah variable yang akan diukur dalam penelitian ini.

1. E-learning self efficacy

Park (2009) mendefinisikan E-learning self efficacy menggambarkan kepercayaan diri seseorang untuk mendapatkan informasi dan melakukan komunikasi dengan pengelola sistem elearning serta merupakan keterampilan yang dibutuhkan dalam menggunakan sistem tersebut.

2. Subjective norm

Merupakan norma yang dipengaruhi dab berhubungan dengan perilaku dan konteks sosial[5][6], yang digunakan untuk mengungkapkan keyakinan seseorang tentang bagaimana pengguna dilihat oleh kelompok referensinya ketika melakukan perilaku tertentu [7].

3. System Accessibility(SA)

Merupakan sejauh mana produk, system, layanan, lingkungan dan informasi dapat diakses oleh orang-orang dengan usaha yang relatif rendah [3]. Sedangkan menurut [8], aksesibilitas adalah karakteristik yang dapat diukur; sejauh mana sistem tersebut tersedia dan dapat digunakan oleh individu yang tidak mampu.

4. Perceived usefulness (PU)

Merupakan suatu tahapan dimana seseorang memiliki kepercayaan bahwa dengan menggunakan system dapat membantu meningkatkan kinerja pada saat bekerja, serta dapat memberikan kegunaan dalam melakukan sesuatu. [9]

5. Perceived ease of use (PEOU)

Merupakan suatu tahapan dimana seseorang memiliki kepercayaan bahwa menggunakan sistem tersebut tak perlu bersusah payah dan system dapat memberikan kemudahan dalam melakukan sesuatu [9].

6. E-learning attitude (EA)

Merupakan sikap seseorang yang memiliki kecenderungan untuk menerima atau menolak sesuatu berdasarkan pengalaman dan norma (predisposisi) terhadap perilaku tertentu dan merupakan hasil dari keyakinannya mengenai perilaku tertentu. Berdasarkan penelitian terhadap pengguna e-banking di Nigeria ditemukan hasil berupa self-efficacy berdampak terhadap attitude[10]. Akan tetapi berdasarkan penelitian yang dilakukan oleh [11] terhadap mahasiswa di Korea Selatan diperoleh hasil yang berbeda yaitu selfefficacy tidak berpengaruh terhadap sikap.

7. Intention to use (ItU)

Merupakan suatu kecenderungan perilaku pengguna untuk menggunakan suatu teknologi. Prediksi tingkat penggunaan teknologi komputer pada seseorang dapat dilihat dari sikap perhatiannya terhadap teknologi tersebut, seperti bagaimana keinginanan pengguna menambah perangkat pendukung, tingginya motivasi untuk tetap menggunakan perangkat, serta keinginan pengguna untuk memotivasi pengguna lain [9].

8. User satisfaction

Definisi dari kepuasan pengguna yaitu evaluasi pengguna dari perbedaan antara harapan sebelumnya dengan hasil akhir [12]. Jika berdasarkan evaluasi diperoleh kinerja yang didapatkan sesuai atau lebih dari harapan, maka dapat dikatakan bahwa pengguna tersebut merasa puas, begitu pun sebaliknya. Dalam penggunaan system berbasis online, kepuasan pengguna dapat didefinisikan sebagai kepuasan yang berhubungan dengan pengalaman online sebelumnya [13] .

\section{Analisis Data}

\section{Validitas Instrumen}

Jenis validitas instrumen yang dapat digunakan adalah :

a. Face Validity, jenis instrumen yang disusun berdasarkan landasan teori atau pendapat pakar

b. Criteria validity, jenis instrumen yang diukur dengan menghitung hubungan antara skor dari masing-masing item dengan skor total menggunakan hubungan dengan product moment. Jika didapatkan hasil berupa koefisien korelasi positif dan $>0,3$, maka indicator penelitian dianggap valid [14].

\section{Reliabilitas Instrumen}

Pada penelitian ini menggunakan ukuran reliabilitas koefisien alpha Cronbach, dimana jika diperoleh nilai alpha $>0,6$ maka 
menunjukkan hasil berupa intrumen yang disusun bernilai reliabel[15].

\section{HASIL DAN PEMBAHASAN}

\section{Uji Validitas Instrumen Penelitian}

Pembuatan instrumen penelitian ini disusun menggunakan skala Likert dengan 5 skala, skor terendah bernilai 1 dan nilai tertinggi diberi nilai 5. Alternatif jawaban yang tersedia yaitu "Sangat Setuju" bernilai 5, "setuju" dengan nilai 4, "cukup" bernilai 3, "Kurang setuju" bernilai 2 dan "tidak setuju" bernilai 1. Skala ini digunakan karena dapat mengungkapkan nilai sikap/ perilaku atau perasaan responden.

Pada Uji Validitas, indikator penelitian dikatakan valid jika nilai loading factor yang dihasilkan bernilai di atas 0,5 terhadap konstruk yang dituju. Output SmartPLS untuk loading factor memberikan hasil sebagai berikut.

\section{A. E-Learning Self Efficacy}

Berdasarkan pengujian yang dilakukan terhadap item kuisioner E-Learning Self Efficacy diperoleh nilai loading factor seperti pada tabel 1.

Tabel 1. Item Kuisioner E-Learning Self Efficacy

\begin{tabular}{|c|l|c|}
\hline No. & \multicolumn{1}{|c|}{ Pertanyaan/Pernyataan } & $\begin{array}{c}\text { Loading } \\
\text { Factor }\end{array}$ \\
\hline 1 & $\begin{array}{l}\text { Saya yakin dapat menemukan } \\
\text { informasi yang terdapat pada e- } \\
\text { learning Poliban }\end{array}$ & $\mathbf{0 . 8 7 5}$ \\
\hline 2 & $\begin{array}{l}\text { Saya mampu menggunakan e- } \\
\text { learning Poliban }\end{array}$ & $\mathbf{0 . 9 0 3}$ \\
\hline
\end{tabular}

\section{B. Subjective norm}

Berdasarkan pengujian yang dilakukan terhadap item kuisioner Subjective norm diperoleh nilai loading factor seperti pada tabel 2.

Tabel 2. Item Kuisioner Subjective norm

\begin{tabular}{|c|l|c|}
\hline No. & \multicolumn{1}{|c|}{ Pernyataan/ Pertanyaan } & $\begin{array}{c}\text { Loading } \\
\text { Factor }\end{array}$ \\
\hline 3 & $\begin{array}{l}\text { e-learning penting bagi saya } \\
\text { sebagai Dosen }\end{array}$ & $\mathbf{0 . 9 1 5}$ \\
\hline & $\begin{array}{l}\text { Saya suka menggunakan e- } \\
\text { learning berdasarkan kesamaan } \\
\text { nilai-nilai saya dan nilai-nilai } \\
\text { masyarakat yang mendasari } \\
\text { penggunaannya }\end{array}$ & $\mathbf{0 . 8 5 3}$ \\
\hline 5 & $\begin{array}{l}\text { Agar saya bisa mempersiapkan } \\
\text { diri untuk pekerjaan masa depan, } \\
\text { perlu menguasai e-learning }\end{array}$ & $\mathbf{0 . 8 1 3}$ \\
\hline
\end{tabular}

\section{System Accessibility}

Berdasarkan pengujian yang dilakukan terhadap item kuisioner System Accessibility diperoleh nilai loading factor seperti pada tabel 3.

Tabel 3. Item Kuisioner System Accessibility

\begin{tabular}{|c|l|c|}
\hline No. & \multicolumn{1}{|c|}{ Pernyataan/ Pertanyaan } & $\begin{array}{c}\text { Loading } \\
\text { Factor }\end{array}$ \\
\hline 6 & $\begin{array}{l}\text { Saya tidak mengalami kesulitan } \\
\text { mengakses dan menggunakan } \\
\text { sistem e-learning Poliban }\end{array}$ & 1.000 \\
\hline
\end{tabular}

\section{Perceived usefulness}

Berdasarkan pengujian yang dilakukan terhadap item kuisioner Perceived usefulness diperoleh nilai loading factor seperti pada tabel 4.

Tabel 4. Item Kuisioner Perceived usefulness

\begin{tabular}{|c|l|c|}
\hline No. & \multicolumn{1}{|c|}{ Pernyataan/ Pertanyaan } & $\begin{array}{c}\text { Loading } \\
\text { Factor }\end{array}$ \\
\hline 7 & $\begin{array}{l}\text { E-learning akan meningkatkan } \\
\text { kinerja saya }\end{array}$ & $\mathbf{0 . 9 3 8}$ \\
\hline 8 & $\begin{array}{l}\text { E-learning akan meningkatkan } \\
\text { produktivitas akademik }\end{array}$ & $\mathbf{0 . 9 1 6}$ \\
\hline 9 & $\begin{array}{l}\text { E-learning dapat mempermudah } \\
\text { mempelajari bahan perkuliahan }\end{array}$ & $\mathbf{0 . 8 5 2}$ \\
\hline
\end{tabular}

\section{E. Perceived ease of use}

Berdasarkan pengujian yang dilakukan terhadap item kuisioner Perceived ease of use diperoleh nilai loading factor seperti pada tabel 5.

Tabel 5. Item Kuisioner Perceived ease of use

\begin{tabular}{|c|l|c|}
\hline No. & \multicolumn{1}{|c|}{ Pernyataan/ Pertanyaan } & $\begin{array}{c}\text { Loading } \\
\text { Factor }\end{array}$ \\
\hline 10 & $\begin{array}{l}\text { Sistem e-learning mudah } \\
\text { digunakan }\end{array}$ & $\mathbf{0 . 9 0 1}$ \\
\hline 11 & $\begin{array}{l}\text { Bagi saya, mempelajari cara } \\
\text { menggunakan sistem e-learning } \\
\text { itu mudah }\end{array}$ & $\mathbf{0 . 9 0 3}$ \\
\hline 12 & $\begin{array}{l}\text { Sangat mudah untuk menjadi } \\
\text { terampil dalam menggunakan } \\
\text { sistem e-learning }\end{array}$ & $\mathbf{0 . 8 9 0}$ \\
\hline
\end{tabular}

\section{F. E-learning attitude}

Berdasarkan pengujian yang dilakukan terhadap item kuisioner E-learning attitude diperoleh nilai loading factor seperti pada tabel 6. 
Tabel 6. Item Kuisioner E-learning attitude

\begin{tabular}{|c|l|c|}
\hline No. & \multicolumn{1}{|c|}{ Pernyataan/ Pertanyaan } & $\begin{array}{c}\text { Loading } \\
\text { Factor }\end{array}$ \\
\hline 13 & $\begin{array}{l}\text { Belajar melalui e-learning } \\
\text { adalah ide yang bagus }\end{array}$ & $\mathbf{0 . 9 1 6}$ \\
\hline 14 & $\begin{array}{l}\text { Belajar melalui e-learning } \\
\text { adalah ide yang bijak }\end{array}$ & $\mathbf{0 . 9 3 9}$ \\
\hline 15 & $\begin{array}{l}\text { Saya setuju dengan penerapan } \\
\text { e-learning }\end{array}$ & $\mathbf{0 . 8 9 8}$ \\
\hline
\end{tabular}

\section{G. Intention to use}

Berdasarkan pengujian yang dilakukan terhadap item kuisioner Intention to use diperoleh nilai loading factor seperti pada tabel 7.

Tabel 7. Item Kuisioner Intention to use

\begin{tabular}{|c|l|c|}
\hline No. & \multicolumn{1}{|c|}{ Pernyataan/ Pertanyaan } & $\begin{array}{c}\text { Loading } \\
\text { factor }\end{array}$ \\
\hline 16 & $\begin{array}{l}\text { Saya bermaksud untuk sering } \\
\text { memeriksa pengumuman dari } \\
\text { sistem e-learning }\end{array}$ & $\mathbf{0 . 9 1 9}$ \\
\hline 17 & $\begin{array}{l}\text { Saya bermaksud untuk } \\
\text { menjadi pengguna sistem e- } \\
\text { learning yang baik }\end{array}$ & $\mathbf{0 . 9 2 4}$ \\
\hline
\end{tabular}

\section{H. User satisfaction}

Berdasarkan pengujian yang dilakukan terhadap item kuisioner User satisfaction diperoleh nilai loading factor seperti pada tabel 8.

Tabel 8. Item Kuisioner User satisfaction

\begin{tabular}{|c|l|c|}
\hline No. & \multicolumn{1}{|c|}{ Pernyataan/ Pertanyaan } & $\begin{array}{c}\text { Loading } \\
\text { Factor }\end{array}$ \\
\hline 18 & $\begin{array}{l}\text { Puas dengan kelengkapan/fitur } \\
\text { yang ada di e-learning }\end{array}$ & $\mathbf{0 . 9 0 9}$ \\
\hline 19 & $\begin{array}{l}\text { Puas terhadap tampilan/user } \\
\text { interface e-learning }\end{array}$ & $\mathbf{0 . 9 4 2}$ \\
\hline 20 & $\begin{array}{l}\text { e-learning bersifat } u \text { ser } \\
\text { friendly }\end{array}$ & $\mathbf{0 . 8 9 1}$ \\
\hline 21 & $\begin{array}{l}\text { e-learning memberikan respon } \\
\text { tepat waktu }\end{array}$ & $\mathbf{0 . 9 1 5}$ \\
\hline
\end{tabular}

Gambar 3 berikut adalah diagram loading factor masing-masing indikator dalam model penelitian.

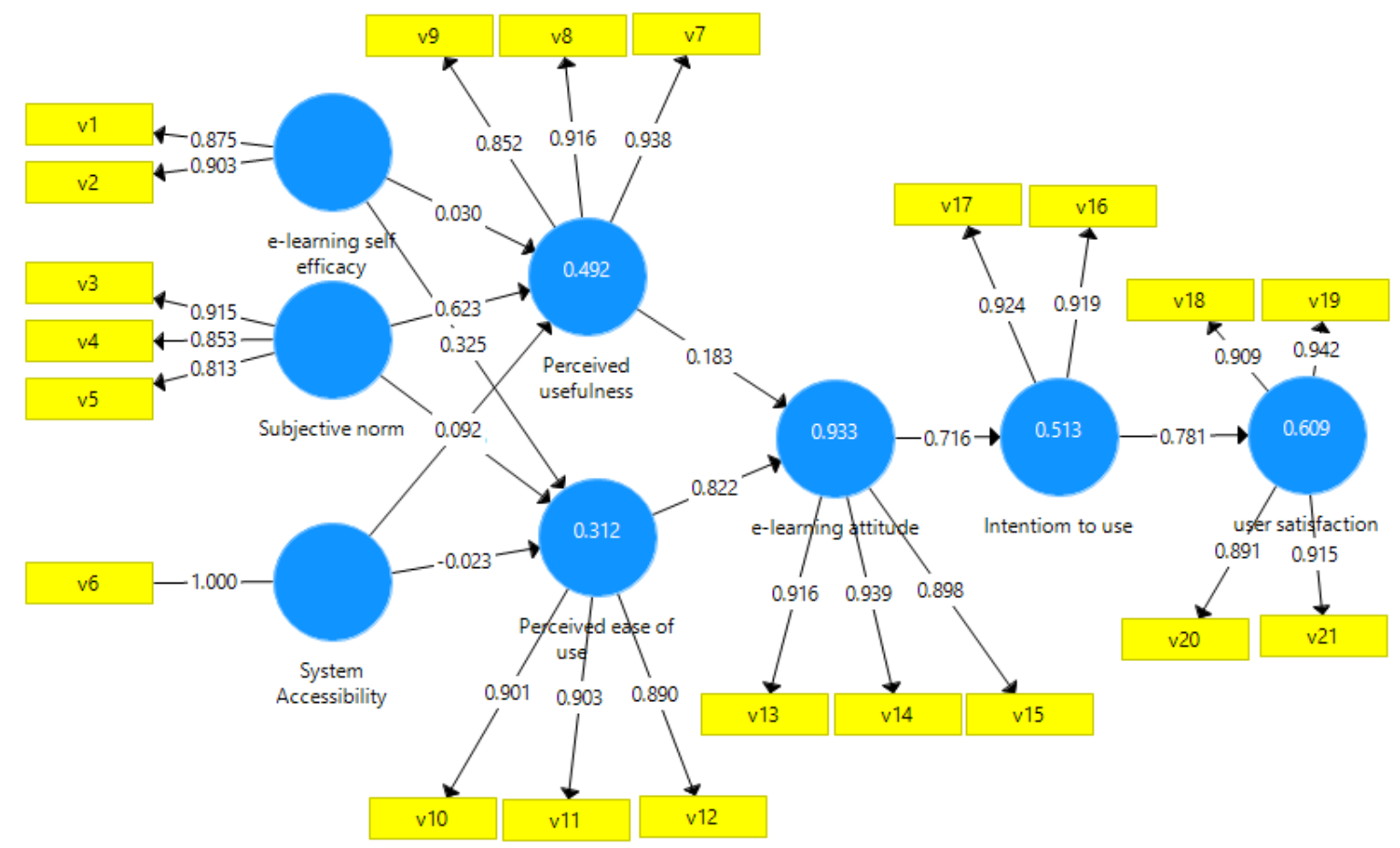

Gambar 3. Diagram Loading Factor 
Berdasarkan nilai loading factor dari seluruh pertanyaan diatas hasil loading factor menunjukkan nilai diatas 0,5 yang memiliki makna bahwa item pertanyaan bernilai valid.

\section{Uji Reliabilitas Instrumen Penelitian}

Hasil pengujian terhadap instrumen penelitian secara keseluruhan menggunakan uji reliabilitas menunjukkan nilai koefisien reliabilitas Cronbach's Alpha seperti pada pada tabel 9. Hasil ini telah sesuai dengan kriteria yang telah ditentukan. Berdasarkan hasil pengujian nilai Cronbach's Alpha yang diperoleh nilai lebih besar dari 0,60. Sehingga berdasarkan hasil tersebut menunjukkan bahwa data hasil angket memiliki tingkat reliabilitas yang baik, atau dengan kata lain data hasil angket dapat dipercaya.

Tabel 9.Cronbach's Alpha dan Composite Reliability

\begin{tabular}{|l|r|r|} 
& Cronbach's Alpha & Composite Reliability \\
\hline Intentiom to use & 0.823 & 0.919 \\
\hline Perceived ease of use & 0.881 & 0.926 \\
\hline Perceived usefulness & 0.885 & 0.929 \\
\hline Subjective norm & 0.825 & 0.896 \\
\hline System Accessibility & 1.000 & 1.000 \\
\hline e-learning attitude & 0.906 & 0.941 \\
\hline e-learning self efficacy & 0.736 & 0.883 \\
\hline user satisfaction & 0.935 & 0.953 \\
\hline
\end{tabular}

Sumber: Output SmartPLS

Pada tabel 9 menunjukan bahwa nilai composite reliability untuk semua konstruk diperoleh nilai lebih besar 0,7 hal ini menunjukkan bahwa semua konstruk pada model penelitian, diestimasi telah memenuhi kriteria dari discriminant validity. Nilai composite reliability yang peling rendah adalah sebesar 0,837 pada konstruk Kualitas Sistem

\section{PENUTUP}

\section{Kesimpulan}

Berdasarkan hasil pengujian validitas menunjukkan bahwa setiap item pertanyaan kuisioner diperoleh nilai loading factor diatas 0,5 yang berarti item tersebut bersifat valid.

Berdasarkan hasil pengujian reliabilitas menunjukan bahwa nilai composite reliability untuk semua konstruk diperoleh nilai lebih besar dari 0,7 hal ini menunjukkan semua konstruk pada model penelitian, diestimasi telah memenuhi kriteria dari discriminant validity.
Instrumen yang dipergunakan dalam penelitian bersifat valid dan dapat dipercaya

\section{Saran}

Dari temuan diatas maka item pertanyaan dalam instrument penelitian dapat digunakan untuk tahapan penelitian selanjutnya yaitu pengukuran implementasi E-learning terhadap kepuasan pengguna pada masa pandemic COVID 19 di Lingkungan Politeknik Negeri Banjarmasin.

\section{REFERENSI}

[1] R. Indonesia, "Peraturan Presiden Nomor 72 Tahun $2 \mathrm{O} 19$ tentang Kementerian Pendidikan dan Kebudayaan," no. 009545, 2019.

[2] M. Pendidikan, D. A. N. Kebudayaan, and $\mathrm{R}$. Indonesia, "PERATURAN MENTERI PENDIDIKAN DAN KEBUDAYAAN TENTANG STANDAR NASIONAL PENDIDIKAN TINGGI.," pp. 2013-2015, 2013.

[3] M. P. Berlianto, "Anteseden dan Konsekuensi Kepuasan terhadap Penggunaan E-Learning pada Mahasiswa," J. Ekon. dan Bisnis, vol. 20, no. 2, p. 229, 2017, doi: 10.24914/jeb.v20i2.1023.

[4] B. W. Surya and D. Makhmudin, "Kajian Perilaku Pengguna e-Learning dengan menggunakan pendekatan Technology Acceptance Model ( TAM ) ( Studi Kasus: e-learning Universitas Padjadjaran )," vol. 13, no. 1, pp. 1-9, 2019.

[5] H. K. Yau and A. L. F. Cheng, "The influence of study mode on the confidence in using technology for learning: An empirical study in hong kong higher education," Lect. Notes Eng. Comput. Sci., vol. 2203, pp. 909-911, 2013.

[6] V. Venkatesh and F. D. Davis, "Theoretical extension of the Technology Acceptance Model: Four longitudinal field studies," Manage. Sci., vol. 46, no. 2, pp. 186-204, 2000, doi: 10.1287/mnsc.46.2.186.11926.

[7] A. Al-Swidi, S. M. R. Huque, M. H. Hafeez, and M. N. M. Shariff, "The role of subjective norms in theory of planned behavior in the context of organic food consumption," Br. Food J., vol. 116, no. 
10, pp. 1561-1580, 2014, doi: 10.1108/BFJ-05-2013-0105.

[8] S. J. Laskowski, "Improving the Usability \& Accessibility of Voting Systems \& Products." 2015.

[9] F. D. Davis, "Perceived usefulness, perceived ease of use, and user acceptance of information technology," MIS Q. Manag. Inf. Syst., vol. 13, no. 3, pp. 319-339, 1989, doi: 10.2307/249008.

[10] C. Adesina, A.A. \& Ayo, "An Empirical Investigation of the Level of Users' Acceptance of E - Banking in Nigeria," $J$. Internet Bank. Commer., vol. 15, 2010.

[11] S. Y. Park, "An Analysis of the Technology Acceptance Model in Understanding University Students," $J$. Educ. Technol. Soc., vol. 12, no. 3, 2009.

[12] R. L. Oliver, "A Cognitive Model of the Antecedents and Conseqences of Satisfaction Decisions," J. Mark. Res., vol. 17, no. 4, 1980, doi: https://doi.org/10.1017/CBO9781107415 324.004.

[13] R. E. Anderson and S. S. Srinivasan, "ESatisfaction and E-Loyalty: A Contingency Framework," Psychol. Mark., vol. 20, no. 2, pp. 123-138, 2003, doi: 10.1002/mar.10063.

[14] Solimun, Structural Equation Modeling (SEM). Malang: Universitas Brawijaya, 2005.

[15] U. Sekaran, Reserch Methods for Business: A Skill Building Approach, edisi 4., John Willey \& Sons. Jakarta: Salemba Empat, 2006. 